\title{
HLA-KIR Compound Genotype
}

National Cancer Institute

\section{Source}

National Cancer Institute. HLA-KIR Compound Genotype. NCI Thesaurus. Code C126415.

The combination of polymorphisms in the DNA encoding human leukocyte antigens

(HLA) and killer-cell immunog lobulin-like receptors (KIR) found in an individual's genome.

Certain combinations may indicate that the subject is more likely to develop certain diseases such as autoimmune disorders, viral infections, and cancer. 